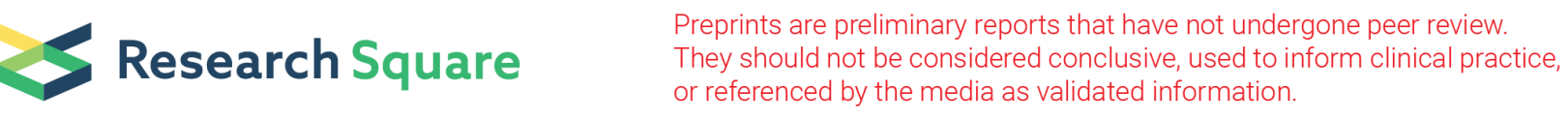

\title{
Evaluation of anthropogenic nexus on groundwater quality through integration of hydrogeochemical processes and water quality index at Nacharam watershed of greater Hyderabad, India
}

Rama Mohan Kurakalva ( $\sim$ krenviron@ngri.res.in )

NATIONAL GEOPHYSICAL RESEARCH INSTITUE (CSIR) https://orcid.org/0000-0001-7199-7475

Sravya Sai Guddeti

NGRI: National Geophysical Research Institute CSIR

Anjana Nath

Kerala University of Fisheries and Ocean Studies

Eswara Venkata Ravi Kishore Vemana

NGRI: National Geophysical Research Institute CSIR

\section{Research Article}

Keywords: Groundwater quality, Pollution Vulnerability, WQI integrated with GIS, Anthropogenic impact, Nacharam watershed, Hyderabad

Posted Date: October 20th, 2021

DOl: https://doi.org/10.21203/rs.3.rs-990861/v1

License: (c) (i) This work is licensed under a Creative Commons Attribution 4.0 International License. Read Full License 


\section{Abstract}

Anthropogenic activities such as the rapid leap of industrialization and urbanization constitute a significant concern in megacities and have become a key source of groundwater contamination. Twenty-five (25) groundwater samples were collected from tube wells and handpumps from Nacharam watershed, greater Hyderabad. The water samples were analyzed for 13 physicochemical parameters and major dissolved ions using the standard methods. WQI has been computed using a weighted arithmetic index method and integrated with GIS to identify the hotspots of contamination and their spatial distribution. The analytical data plotted on the Piper diagram showed that dominance of $\mathrm{Ca}-\mathrm{Mg}-\mathrm{Cl}(52 \%)$ type followed by $\mathrm{Na}-\mathrm{Cl}$ type of water is dominant in $44 \%$ of samples might be resulting due to increase in anthropogenic activities such as discharge of waste water from industries. Results reveal that $96 \%$ of the samples exceed the $\mathrm{F}$ - concentrations compared with WHO permissible limits suggested unfit for drinking. WQI values indicate that $56 \%$ of samples fall in the poor category, $28 \%$ belong to very poor water, and $4 \%$ are unsuitable for drinking. These findings will provide valuable information to policymakers and stakeholders on the proper management and supply of potable water that reduces human health concerns .

\section{Introduction}

Contamination of groundwater resources has developed as a significant issues world wide. Groundwater is considered polluted when it contains enough foreign matter to evince it unfit for human consumption and other recreational uses (Khatri et al. 2016; Rawtani et al., 2017). Because of rapid industrialization and urbanization, numerous industries in and around the urban areas release their untreated and semi-treated effluents into nature, contaminating water bodies. Toxins, for example, substantial metals and different synthetics, which are present in the effluents dislodged through the soil, surface water, residue of the lake bed and permeated into groundwater, influencing its quality. Groundwater quality assumes significance in deciding the use of groundwater for a particular reason. Water for drinking must be free from harmful components, exorbitant minerals that may affect human well-being (Reddy et al., 2019; Vaiphe and Kurakalva, 2020). Efficient observation is profoundly required because all human health problems are straightforwardly connected with water quality. Natural and anthropogenic factors influence groundwater physical and chemical patterns in an area, thereby deteriorating the quality (Subramanian 2009; Khatri and Tyagi, 2015).

In a provincial domain, groundwater, lake water, waterway water, and channel water fill in as significant wellsprings of drinking water. Among these water resources, groundwater is the most generally utilized drinking water source in greater Hyderabad, one of the largest metropolitan cities in India (Kurakalva et al. 2021). This city has wellsprings of contamination, for example, landfills, risky sewer lines, squander lands result which leads to groundwater contamination. Inappropriately treated effluents, underground stockpiling tanks, spills, and draining of harmful synthetic compounds are the major sources of contamination and significantly influence groundwater quality (Garewal and Vasudeo, 2018; Santucci et al. 2018). It has been perceived that most of the industrial areas/towns release their effluents into the streams, and the solid waste created is discretionarily dumped on open land along lanes and lakes (Krishna and Mohan 2014; Vaiphei and Kurakalva 2021a). Groundwater has a more prominent break-up substance because of its expanded cooperation with various materials in the geologic layers (CPCB, 2007) comparatively with surface water.

Understanding hydrogeochemical processes are helpful for effective utilization, protection, and prediction of spatial and temporal variations in groundwater quality (Kadam et al. 2021; Vaiphe and Kurakalva 2021b). The WQI method is generally utilized for groundwater quality appraisal worldwide because of the capability of complete communication of the water quality data. There is insufficient knowledge about groundwater pollution at the Nacharam Watershed of greater Hyderabad, India (Bhoopathi et al. 2014; Rao et al. 2016). Besides, the watershed has various types of major industrial clusters overlapped with the habitats where groundwater is the primary source for drinking and other domestic uses. The anthropogenic activities further lead to vulnerability to impact on groundwater quality in the region. Consequently, a detailed investigation on groundwater characterization, the impact of anthropogenic activities, and their spatial distribution of contamination of great environmental and public health concerns. The present study's objective is to assess the impact of anthropogenic activity on the groundwater quality in the Nacharam watershed based on hydrogeochemical characterization and use of an integrated approach of GIS and WQI. The developed WQI distribution map can be used as tool visiualize spatially the groundwater quality of the Nacharam watershed.

Page $2 / 20$ 


\section{Materials And Methods}

\subsection{About study area}

Nacharam watershed is located in North-East of Hyderabad, Medchal Malkajgiri district. This watershed also includes the industrial area developed in an area of approximately 700 acres. The study area lies between latitudes $17^{0} 23^{\prime} 30^{\prime \prime} \mathrm{N}$ to $17^{\circ}$ $26^{\prime} 30^{\prime \prime} \mathrm{N}$ and longitudes $78^{\circ} 32^{\prime} 30^{\prime \prime} \mathrm{E}$ to $78^{\circ} 36^{\prime} 30^{\prime \prime} \mathrm{E}$ and falls in Survey of India toposheet No.56K/11/NW. The study area spreads about 53 Sq.km. Approximately 100 industries, including steel manufacturing, chemical manufacturing, food processing, rubber, plastic, and distilleries, are located in the study area. The watershed consists of the industrial estate is demarcated. The location map of the Nacharam watershed and sampling stations are shown in Figure 1. The study area consists of significant rock formation of medium to coarse-grained granite and presumed as part of the peninsular gneissic complex (GSI, 1995). The district is underline with various geological formations such as Archean granites and gneisses, Bhima series, and Deccan traps. The Archean crystalline rocks compressing older metamorphic rocks, peninsular gneissic complex (migmatites), and younger intrusive rocks. Intrusive dolerite dyke any common in this area (CGWB, 2015).

\subsection{Groundwater sampling and analysis}

Groundwater samples are collected from 25 bore wells of the Nacharam watershed according to the grid pattern (size:1 1 km) in the Nacharam watershed of greater Hyderabad, Telangana. A sampling protocol is followed according to APHA (2017) standard methods and collected in polypropylene bottles. The sampling bottles were rinsed 2-3 times with sampling water and filled to avoid air-water interaction. The $\mathrm{pH}, \mathrm{EC}$, and TDS values are measured in situ immediately without filtration on the same day after collecting the samples. Bicarbonate $\left(\mathrm{HCO}_{3}{ }^{-}\right)$concentrations were determined by titration using $0.02 \mathrm{~N} \mathrm{H}_{2} \mathrm{SO}_{4}$ as titrant. Major anions and cations concentration in groundwater samples were determined using lon chromatograph (882 Compact IC plus, Metrohm).

\subsection{Water Quality Index}

Water quality index (WQI) of each sample was carried out to assess the suitability of grondwater for drinking use. World Health Organization guideline values (WHO, 2017) were usedto compute WQI. The WQI has been computed using a weighted arithmetic index method as described by Brown et al. (1970) using the following equation (1).

$\mathrm{q}_{\mathrm{n}}=100\left[\left(\mathrm{~V}_{\mathrm{n}}-\mathrm{V}_{\mathrm{i}}\right) /\left(\mathrm{S}_{\mathrm{n}}-\mathrm{V}_{\mathrm{i}}\right)\right] \quad$ eq. $(1)$

Where $\mathrm{q}_{\mathrm{n}}=$ Water quality rating for the $\mathrm{n}^{\text {th }}$ parameter; $\mathrm{V}_{\mathrm{n}}=$ Observed value of the $\mathrm{n}^{\text {th }}$ parameter, $\mathrm{S}_{\mathrm{n}}=$ Standard permissible value of $n^{\text {th }}$ parameter; $\mathrm{V}_{\mathrm{i}}=$ Ideal value of $\mathrm{n}^{\text {th }}$ parameter

The unit weight $(\mathrm{Wn})$ of the each parameter was an inverse proportional value to the recommended standard value of $\mathrm{Sn}$ and calculated as per the following equation (2)

$W_{n}=K / S_{n} \quad$ eq. (2)

Where,$W n=$ Unit weight for the $\mathrm{n}^{\text {th }}$ parameter; $\mathrm{Sn}=$ Standard value of the $\mathrm{n}^{\text {th }}$ parameter; $\mathrm{K}=$ Constant for proportionality which is calculated by using equation (3)

$K=1 / \Sigma\left(1 / S_{n}\right)$

Finally, the total water quality index was calculated linearly by adding the quality rating to the unit weight according to equation (4)

$W Q I=\Sigma q_{n} W_{n} / \Sigma W_{n} \quad$ eq. (4)

WQI has been calculated using the relative weight for each parameter, as presented in Table 1. Groundwater quality in the Nacharam watershed, Hyderabad was used to appraise for drinking purposes from the developed WQI. 


\section{Results And Discussion}

Analytical data of physicochemical parameters, major ions in all the groundwater samples are presented in Table S1. In contrast, the statistical summary of the data compared with WHO permissible limits is represented in Table 2. Hydrogeochemical processes are an effective tool for evaluating groundwater quality and establishing contamination status. Integrating WQI values in the GIS platform is the best tool to identify contamination hotspots and their distribution pattern in the study area. The detailed discussion of the data obtained is illustrated below.

\subsection{Groundwater quality evaluation}

\subsubsection{Physicochemical properties}

Physicochemical properties of groundwater have been evaluated for its suitability for drinking purposes following WHO (2017) permissible limits. $\mathrm{pH}$ is significant in arranging numerous sorts of geochemical balance. $\mathrm{pH}$ of groundwater observed in the ranges from 6.0 to 7.9, indicating alkaline nature, and their spatial distribution is shown in Fig.2 (a). pH values for all the samples are within acceptable limits. Water with a pH higher than 8.5 or lower than 6.5 can produce aesthetic effects such as staining and etching or equipment scaling. The EC values in found in ranges from 410 to $2020 \mu \mathrm{S} / \mathrm{cm}$. (Table 2) and their spatial distribution is shown in Fig.2(b). The high value of TDS influences the taste, hardness, and corrosive property of the water (Devi et al., 2003). TDS varied from 262 to $1293 \mathrm{mg} / \mathrm{L}$ with a mean of $744 \mathrm{mg} / \mathrm{L}$ (Table 2). Both EC and TDS values exceed the permissible limits of WHO guideline values in $16 \%$ of the groundwater samples. The spatial distribution of TDS is presented in Fig.2(c). The acceptable limit of $\mathrm{TH}$ is $100 \mathrm{mg} / \mathrm{L}$ as $\mathrm{CaCO}_{3}$, however, if no alternative source of water it can be used up to $500 \mathrm{mg} / \mathrm{L}$ and is given in Fig. 2(d). About $16 \%$ of the samples exceed the acceptable limits of TH as shown in Table 2.

\subsubsection{Dissolved ions}

The sum of all dissolved ions particles (<2 microns) in groundwater is referred to as TDS, while total hardness (TH) is mainly due to alkaline earth elements like calcium and magnesium ions. TDS and TH values obtained for groundwater of the study area have been categorized with different classifications as described (Davis and Dewiest 1966; Freeze and Cherry 1979; Sawyer et al. 2003) and presented in Table 3. The present study indicated that most of the groundwater is within permissible limits of $84 \%$ for drinking and $16 \%$ for irrigation purposes. TDS in groundwater is due to the percolation of industrial effluents observed in the eastern side of the industrial area (Fig. 2(c)). Based on the TH values (mg/L) in groundwater, classified as soft $(<75)$, moderately high (75-150), hard (150-300), and very hard (>300) water that can be used to evaluate its suitability for drinking and other domestic purposes (Sawyer et al., 2003). The groundwater in the study area belonging to $4 \%$ is moderately high, $24 \%$ belongs to hard type, $72 \%$ of samples belongs to very hard type, and no sample is found in the soft water category. These indicate that most of the samples in the study region belonging to hard to very hard types and are not suitable for drinking. The spatial distribution of hardness in the watershed is shown in Fig.2(d).

\subsubsection{Groundwater major ion chemistry}

Alkali $\left(\mathrm{Na}^{+}, \mathrm{K}^{+}\right)$and alkaline earth $\left(\mathrm{Ca}^{+}\right.$and $\left.\mathrm{Mg}^{+}\right)$elements are the most abundant in natural waters. The order of abundance of the cations was observed as $\mathrm{Na}>\mathrm{Ca}>\mathrm{Mg}>\mathrm{K}$. Sodium is the highest concentration among the cations ranges from 30.01 to 215.01 $\mathrm{mg} / \mathrm{L}$ with a average value of $105.35 \mathrm{mg} / \mathrm{L}$ (Table 1). The WHO acceptable limit of $200 \mathrm{mg} / \mathrm{L}$ exceed in $4 \%$ of samples only. Silicate weathering is the primary source for resulting $\mathrm{Na}^{+}$in groundwater resources. Then, calcium is the next higher concentration found in the groundwater, varying from 12.22 to $88.67 \mathrm{mg} / \mathrm{L}$ and mean value of $47.23 \mathrm{mg} / \mathrm{L}$ (Table 1). Magnesium values varied between 6.16 and $45.11 \mathrm{mg} / \mathrm{L}$, and the average values of $23.70 \mathrm{mg} / \mathrm{L}$ were observed (Table 2). The required, acceptable limit of magnesium in groundwater for drinking purposes is $50-150 \mathrm{mg} / \mathrm{L}(\mathrm{WHO}, 2017)$. All the groundwater samples are within the given permissible limits. Potassium concentration of the groundwater ranging from 0.98 to $18.79 \mathrm{mg} / \mathrm{L}$ with an average value of $3.46 \mathrm{mg} / \mathrm{L}$. The acceptable limit of potassium in drinking water is $200 \mathrm{mg} / \mathrm{L}$. Among all the cations in groundwater, the potassium found low concentrations. The spatial distribution of cations is presented in Fig.3 (a) to 3(d). 
The order of abundance of anions was observed as $\mathrm{HCO}_{3}{ }^{-}>\mathrm{SO}_{4}>\mathrm{Cl}^{-}>\mathrm{F}^{-}>\mathrm{NO}_{3}{ }^{-}$in the groundwater of the study area. Bicarbonate $\left(\mathrm{HCO}_{3}{ }^{-}\right)$concentrations found ranges from 73.20 to $549 \mathrm{mg} / \mathrm{L}$ with a mean value of $264.74 \mathrm{mg} / \mathrm{L}$. Around $88 \%$ of the samples exceeded the permissible limits (WHO, 2017) as given in Table 2 and their spatial variation is presented in Fig.3(e). The source of bicarbonates in groundwater is due to the dissolution of carbonate minerals as per equations (5) and (6).

$\mathrm{CaCO}_{3}+\mathrm{CO}_{2}+\mathrm{H}_{2} \mathrm{O} \leftrightarrow \mathrm{Ca}^{2+}+2 \mathrm{HCO}_{3}^{-} \quad$ eq. (5)

$\mathrm{CO}_{2}+\mathrm{H}_{2} \mathrm{O} \leftrightarrow \mathrm{H}^{+}+\mathrm{HCO}_{3}^{-} \quad$ eq. (6)

Sulphate is the most abundant anion next to bicarbonate in the study area, varying from 2.79 to $2374.87 \mathrm{mg} / \mathrm{L}$ with the mean value of $548.22 \mathrm{mg} / \mathrm{L}$ (Table 2), which is above the permissible limit of $250 \mathrm{mg} / \mathrm{L}$ (WHO, 2017). Around $44 \%$ of the groundwater samples exceed the allowable limits (Table 2), and their distributions spatially showed in Fig.3(i). The chloride concentration of the study area ranges from 55.26 to $1101.31 \mathrm{mg} / \mathrm{L}$ with mean of $344.95 \mathrm{mg} / \mathrm{L}$, and spatial distribution is shown in Fig.3(g). The acceptable limit of chloride in potable water is $200-300 \mathrm{mg} / \mathrm{L}(\mathrm{WHO}, 2017)$. Around $52 \%$ of the samples were above the acceptable limits.

Elevated fluoride concentrations were observed range from 0.58 to $7.28 \mathrm{mg} / \mathrm{L}$ with an average of $3.34 \mathrm{mg} / \mathrm{L}$. Acceptable limit of fluoride in potable water is $0.6-1.0 \mathrm{mg} / \mathrm{L}$ (WHO, 2017). Around $96 \%$ of the samples were above the permissible limits, and their spatial variations are shown in Fig.3(f). It is well known that high concentration fluoride in drinking water originates dental decay and physiological deformation. The nitrate concentration of the groundwater samples of the study area found in all the samples are within the permissible limit $(50 \mathrm{mg} / \mathrm{L}$ ) of nitrate in potable water indicates there is no influence of agricultural fertilizers and domestic sewage, which are the major sources.

\subsubsection{Correlation analysis}

Correlation analysis of various physicochemical and major ions of the groundwater has been presented in Table 3. A good correlation (>0.5) was observed between $\mathrm{EC}$ and TDS with $\mathrm{Cl}^{-}, \mathrm{Na}^{+}, \mathrm{SO}_{4}^{-}$and $\mathrm{HCO}_{3}{ }^{-}$. It indicates that concentrations of sodium and chloride concentration might be due to over-exploitation of groundwater resources, a common practice in urban areas (Hem,1985). It is also observed that chloride is derived from anthropogenic activity, such as releasing industrial effluents onto open drainage or land (Sunil Kumar and Ramanathan 2008).

\subsection{Assessment of the impact of anthropogenic sources}

Hydrochemical interactions are the best signatures to illustrates the effects of anthropogenic activities on groundwater resources. Subsequently, the major ion chemistry data plotted in Piper trilinear diagram, and $\mathrm{Na}^{+} / \mathrm{Cl}^{-}$molar ratio to interpenetrate the groundwater contamination.

\subsubsection{Hydrochemical facies and groundwater types}

The Piper trilinear diagram (Piper, 1953) is an effective tool in advocating sources of the dissolved constituents and modifications in the characteristics of groundwater as it passes over an area as well as related geochemical processes. The analytical values obtained for the groundwater samples are plotted on Piper trilinear diagram (Todd 1980) are presented in Fig.4. Geochemical evolution of groundwater can be elucidated from the Piper plot, which has been classified into four facies as shown in Fig.4, they are I) Ca-Mg-Cl-SO ${ }_{4}$ II) Na-K-Cl-SO, III) Na-K-HCO 3, IV) Ca-Mg- $-\mathrm{HCO}_{3}$. From figure 4, it is observed that identified in the study area, $52 \%$ of the samples fall into the $\mathrm{Ca}-\mathrm{Mg}-\mathrm{Cl}-\mathrm{SO}_{4}$ category indicating that water has been changed into saline and hardness might be due to wastewater discharges from industries. Besides, $44 \%$ of samples are in $\mathrm{Na}-\mathrm{K}-\mathrm{Cl}_{-} \mathrm{SO}_{4}$, showing the influence of sodium and chloride. Further, the Piper plot is also divided into six subcategories viz. (1) $\mathrm{Ca}-\mathrm{HCO}_{3},(2) \mathrm{Na}-\mathrm{Cl},(3)$ mixed $\mathrm{Ca}-\mathrm{Na}-\mathrm{HCO}_{3}$, (4) mixed $\mathrm{Ca}-\mathrm{Mg}-\mathrm{Cl}$, (5) $\mathrm{Ca}-\mathrm{Cl}$ type, and (6) $\mathrm{Na}-\mathrm{HCO}_{3}$ to know the groundwater type. In this study region, the majority of the samples are found in mixed $\mathrm{Ca}-\mathrm{Mg}-\mathrm{Cl}(52 \%)$ implies the predominance of reverse ion exchange such as water containing permanent hardness. $\mathrm{Na}-\mathrm{Cl}$ type of water is dominant in $44 \%$ of samples might be due to an increase in industrial water pollution as the time more new ventures are installed (Eitteieb et al. 2017).

Page 5/20 


\subsubsection{Sodium/chloride $\left(\mathrm{Na}^{+} / \mathrm{Cl}^{+}\right)$ratio}

In natural waters presence of sodium ions is due to the atmospheric precipitation, dissolution of evaporating, weathering of silicate minerals, and ion exchange processes (Meybeck, 2004). On the other hand, chloride concentration results from the dissolution of halite (Hounslow, 1995). The $\mathrm{Na} / \mathrm{Cl}$ molar ratio against EC values is plotted and presented in Fig.5. The ratio of $\mathrm{Na} / \mathrm{Cl}$ should be approximately equal to 1 , whereas if the ratio is greater than 1 is typically related to Na release from silicate weathering attributed due to rock water interaction (Pillai et al. 2020 and Rajesh et al. 2012), according to the equation (7) as given below;

eq. (7)
(Albite)
(Silicate weathering)
(Kaolinite)

In this study, $32 \%$ of samples are succeeding the above process, remaining $68 \%$ of samples are fall in $\mathrm{Na} / \mathrm{Cl}$ ratio equal to or less than 1. Further, it is observed that chloride ion is beyond sodium concentration which might be due to the base exchange processes or anthropogenic pollution (Jones et al., 1999, Srinivasamoorty et al. 2014).

\subsection{WQI integrated with GIS}

The evaluation of the suitability of groundwater for drinking purposes obtained for each sample through estimating their respective water quality index (WQI). WQI values of groundwater samples of each sampling site are presented in Table 5 . The WQI observed range from 40.231 to 393.926 . Further groundwater has been classified based on WQI value is shown in Table S2. The classification indicating that $4 \%$ of samples are of excellent and $8 \%$ of samples are of good category, $56 \%$ of samples are falling in the poor category, $28 \%$ of samples belong to very poor water, and $4 \%$ of samples are of unsuitable for drinking. The sample Nos.3,6,9 and 10 falls under the classification of very poor to unsuitable for drinking type that demonstrates anthropogenic activities influences on groundwater resources. The samples from other locations are poor to very poor class that might be due to point sources of domestic effluents leached into groundwater. The generated knowledge would be helpful to the policymakers for proper management and supply of to the public to protect their health.

\section{Conclusion}

Anthropogenic activities and poor effluent management around industrial areas is one of the major cause of pollution of groundwater resources. The study was conducted at Nacharam watershed for water quality assessment based on hydrogeochemical characterization, WQI integrated with GIS techniques. The physicochemical parameters like EC and TH are beyond permissible limits, referring to WHO standards. The spatial distribution of fluoride in groundwater indicates that $96 \%$ of samples are beyond the WHO permissible limits, unfit for drinking. From the Piper diagram classification, it concluded that the dominant groundwater type is Mixed $\mathrm{Ca}^{+2}-\mathrm{Mg}^{+2}-\mathrm{Cl}^{-}$followed by $\mathrm{Na}^{+}-\mathrm{Cl}^{-}$. WQI values found that only $4 \%$ of samples are excellent, and $8 \%$ are of good category, respectively. $56 \%$ of samples are of poor category, $28 \%$ of samples belong to very poor water and $4 \%$ of samples are of unsuitable for drinking. Consequently it indicated that groundwater in the study regions is not suitable for drinking purposes due to anthropogenic activities such as domestic and industrial effluents release. Proper disposal and treatment of urban sewage and effluent before releasing it to the environment should be evaluated with utmost care. The policymakers and NGOs will directly visualize the further spatial distribution of WQI values to treat and supply to the people to protect their health in the study region.

\section{Declarations}

The authors declare that they have no known competing financial interests or personal relationships that could have appeared to influence the work reported in this paper.

\section{Acknowledgements}

Page $6 / 20$ 
The authors would like to thank Prof. V.M. Tiwari, Director of CSIR-NGRI for permission to publish this research work. The authors also acknowledge Environmental Geochemistry Labs, CSIR-NGRI for their support in groundwater samples analysis.

\section{Authors contributions}

Rama Mohan Kurakalva: Conceptulization, analysis and manuscript writing and supervison

Sravya Sai Guddeti: Fieldwork, assist in manuscript writing and interpretation of data

Anjana Nath: Fieldwork, Assist in data processing.

Eswara Venkata Ravi Kishore Vemana: Assist in data processing.

\section{References}

APHA (2017). tandard methods for the examination of water and wastewater $23^{\text {rd }}$ ed. APHA method 4110 , American Public Health Association, Washington DC.

Bhoopathi, V., Kunatamalla, S., Madhusudhan, N., Narasimha A., Rajeswara Reddy, B (2014). Water quality assessment of Nacharam area, Ranga Reddy district, Andhra Pradesh, Global J Bio, Agri \& Health Sci. 3(1), 220-25

Brown, R.M., McClelland, N.I., Deininger R.A., \& Tozer, R.G., (1970). A water quality index: Do we dare? Water and sewage work, 117:339-343.

CGWB (2015), Central Groundwater Board. Groundwater Yearbook Telangana State, 2015-2016, pp. 47-54.

CPCB, (2007). Status of Groundwater Quality in India-Part I. Groundwater Quality Series. Central Pollution Control Boards. Ministry of Environment and Forests, New Delhi.

Devi, G. S., Barbadha, S.B., Hazel, D., Dolly, C., (2003). Physicochemical characteristics of drinking water at Velsao Goa. J. Environ. Monit. 13, 203-209.

Etteieb, S., Cherif, S. \& Tarhouni, J. (2017) Hydrochemical assessment of water quality for irrigation: a case study of the Medjerda River in Tunisia. Appl Water Sci 7, 469-480 https://doi.org/10.1007/s13201-015-0265-3

Garewal, S.K., Vasudeo, A.D. (2018). Causes and sources of groundwater pollution: a case study of Nagpur city, India. In: Singh, V., Yadav, S., Yadava, R. (Eds.), Groundwater. Water Science and Technology Library, vol. 76. Springer, Singapore

Hem, J. D. (1991). Study and interpretation of the chemical characteristics of natural waters (3rd Ed., Book 2254). Jodhpur: Scientific.

Hounslow, A. W. (1995) Water Quality Data: analysis and interpretation, Lewis Publishers, Oklahoma State University Stillwater, Oklahoma, $397 \mathrm{p}$.

Jones, B.F., Vengosh, A., Rosenthal, E., Yechieli, Y (1999), Geochemical investigation of groundwater quality: Seawater intrusion in coastal aquifers-concepts, methods and practices, Kluwer, Netherlands,pp1-71

Kadam, A., Wagh, V., Patil, S., Umrikar, B, Sankhua, R., Jacobs, J (2021) Seasonal variation in groundwater quality and benefical use for drinking, irrigation, and industrial purposes from Deccan Basaltic Region,Western India. Environ Sci Pollut Res 28, 2608226104 https://doi.org/10.1007/s11356-020-12115-x

Khatri, N., Tyagi, S. (2015). Influences of natural and anthropogenic factors on surface and groundwater quality in rural and urban areas. Front. Life Sci. 8:23-39. 
Khatri, N., Tyagi, S., Rawtani, D. (2016). Assessment of drinking water quality and its health effects in rural areas of Harij Taluka, Patan district of Northern Gujarat. Environ. Claims J. 28:223-246.

Krishna, A.K., Mohan, K.R. (2014) Risk assessment of heavy metals and their source distribution in waters of a contaminated industrial site. Environ Sci Pollut Res 21:3653-3669.

Kurakalva, R.M., Kuna, G., Vaipher, S.P., Guddeti, S.S., (2021), Evaluation of hydrogeochemical profile,potential health risk and groundwter quality in rapidly growing urban region of Hyderabad, South India. Environ. Earth Sci. 80, 383

(2021) https://doi.org/10.1007/s12665-021-09661-z

Meybeck, M. (2004) Global occurrence of major elements in rivers, In: Drever, J.I. (Ed.), Surface and ground water, weathering, and soils, Holland, H.D., Turekian, K.K. (Exec. Eds), Treatise on geochemistry, vol. 5, ElsevierPergamon, Oxford, pp. 207-223.

Pillai A V S, Sabarathinam C, Keesari T, Chandrasekar T, Rajendiran T, Senapathi V, Viswanathan P M, Samayamanthu D R (2020) Seasonal Changes in groundwater quality deterioration and chemometric analysis of pollution source identification in South India. Environ Sci Pollut Res 27, 20037-20054. https://doi.org/10.1007/s11356-020-08258-6

Piper, A.M. (1953). A Graphic procedure in the geochemical interpretation of water analysis. U.S.Geological Survey Ground Water Note, 12:63.

Rao, B.V., Kavitha, Ch., Murthy, N.N., Polari, K. (2016). Heavy Metal Contamination of Groundwater in Nacharam Industrial Area, Hyderabad, India. Journal of Indian Geophysical Union. 20 (2), 171-177.

Rawtani, D., Khatri, N., Tyagi, S., Pandey, G. (2017). Nanotechnology-based recent approaches for sensing and remediation of pesticides. J. Environ. Manag. 206, 749-762.

Reddy, B.M., Sunitha, V., Prasad,M., Reddy,Y.S., Reddy, M.R.(2019). Evaluation of groundwater suitability for domestic and agricultural utility in semi-arid region of Anantapur, Andhra Pradesh State, South India. Groundwater Sustainable Development, 9:100262, https://doi.org/10.1016/j.gsd.2019.100262.

Santucci L, Carol E, Tanjal C (2018). Industrial waste as a source of surface and groundwater pollution for more than half a century in a sector of the Río de la Plata coastal plain (Argentina). Chemosphere 206:727-735. doi:

10.1016/j.chemosphere.2018.05.084.

Sawyer, C.N., Mccarty, P.L., Parkin, G.F. (2003). Chemistry for Environmental Engineering and Science, 5thedn. McGraw-Hill, New York, p. 752.

Subramani, T., Rajmohan, N., Elango, L. (2010). Groundwater geochemistry and identification of hydrogeochemical processes in a hard rock region, Southern India. Environ Monit Assess. 162, 123-137. doi:10.1007/ s10661-009-0781-4

Sunil Kumar, S., \& Ramanathan, A. L. (2008). Geochemical assessment of groundwater quality in vicinity of Bhalswa landfill, Delhi, India, using graphical and multivariate statistical methods. Environmental Geology, 53, 1509-1528

Todd, D.K., 1980. Groundwater Hydrology, $2^{\text {nd }}$ edition, Wiley International Editions, John Wiley \& Sons Canada, Limited, pp.535.

Vaiphei, S.P., Kurakalva R.M., 2021a Compreshensive assessment of groundwater quality using heavy metal pollution indices and geospatial technique: a case study from Wanaparthy watershed of upper Krishna River basin, Telangana, India, Environ Earth Sci 80, 594. https://doi.org/10.1007/s12665-021-09794-1

Vaiphei, S.P., Kurakalva R.M., 2021b. Hydrochemical characteristics and nitrate health risk assessment of groundwater through seasonal variations from an intensive agricultural region of upper Krishna River basin, Telangana, India, Ecotoxicology and Environ Safe 213, 112073 https://doi.org/10.1016/j.ecoenv.2021.112073 
Vaiphei, S.P., Kurakalva, R.M., Sahadevan, D.K., 2020. Water quality index and GIS-based technique for assessment of groundwater quality in Wanaparthy watershed, Telangana, India. Environ Sci Pollut. Res, 27(36), pp.45041-45062.

doi.org/10.1007/s11356-020-10345-7

WHO (2017) Guidelines for drinking-water quality, 4th edition, incorporating the $1^{\text {st }}$ addendum, ISBN: 978-92-4-154995-0.

Zhou, Y., Li P. Xue, L., Dong, Z, Li, D (2020) Solute geochemistry and groundwater quality for drinking and irrigation purposes: a case study in Xinle City, North China. Geochemistry 80 (4) 125609

\section{Tables}

Table 1: Relative weight assigned for each parameter to compute water quality index

\begin{tabular}{|c|c|c|c|c|c|c|c|c|c|}
\hline $\begin{array}{l}\text { Chemical } \\
\text { Parameters }\end{array}$ & Sn & $1 / \mathrm{Sn}$ & $\mathrm{K}$ & $\begin{array}{l}W n= \\
\mathrm{K} / \mathrm{Sn}\end{array}$ & $\begin{array}{l}\text { Ideal } \\
\text { Value } \\
\text { (Vi) }\end{array}$ & $\begin{array}{l}\text { Observed } \\
\text { Value (Vn) }\end{array}$ & $\begin{array}{l}\text { Quality } \\
\text { Rating } \\
\text { (Qn) }\end{array}$ & WnQn & WQI \\
\hline $\mathrm{pH}$ & 8.5 & 0.117647 & \multirow[t]{13}{*}{1.187128} & 0.139662 & 7 & 7.9 & 60.00 & 8.3797 & \multirow[t]{14}{*}{39.944} \\
\hline EC & 1500 & 0.000667 & & 0.000791 & 0 & 460 & 30.67 & 0.0243 & \\
\hline TDS & 1500 & 0.000667 & & 0.000791 & 0 & 294 & 19.60 & 0.0155 & \\
\hline $\mathrm{TH}$ & 500 & 0.002 & & 0.002374 & 0 & 112.5 & 22.50 & 0.0534 & \\
\hline $\mathrm{HCO}_{3}^{-}$ & 150 & 0.006667 & & 0.007914 & 0 & 73.2 & 48.80 & 0.3862 & \\
\hline $\mathrm{F}^{-}$ & 1.5 & 0.666667 & & 0.791419 & 0 & 0.58 & 38.67 & 30.602 & \\
\hline $\mathrm{Cl}^{-}$ & 600 & 0.001667 & & 0.001979 & 0 & 76.57 & 12.76 & 0.0253 & \\
\hline $\mathrm{NO}_{3}^{-}$ & 45 & 0.022222 & & 0.026381 & 0 & 1.48 & 3.29 & 0.0868 & \\
\hline $\mathrm{SO}_{4}{ }^{2-}$ & 400 & 0.0025 & & 0.002968 & 0 & 2.79 & 0.70 & 0.0021 & \\
\hline $\mathrm{Na}^{+}$ & 200 & 0.005 & & 0.005936 & 0 & 104.06 & 52.03 & 0.3088 & \\
\hline $\mathrm{K}^{+}$ & 200 & 0.005 & & 0.005936 & 0 & 4.08 & 2.04 & 0.0121 & \\
\hline $\mathrm{Ca}^{2+}$ & 200 & 0.005 & & 0.005936 & 0 & 62.02 & 31.01 & 0.1841 & \\
\hline \multirow[t]{2}{*}{$\mathrm{Mg}^{2+}$} & 150 & 0.006667 & & 0.007914 & 0 & 28.75 & 19.17 & 0.1517 & \\
\hline & & 0.842369 & & 1 & & & & 40.231 & \\
\hline
\end{tabular}

Table 2: Statistical summary of physicochemical parameters, major ions compared with WHO (2017) permissible limits

Table 3: TDS and TH classification of groundwater of the study area 


\begin{tabular}{|c|c|c|c|c|c|c|c|c|}
\hline $\begin{array}{l}\text { Water Quality } \\
\text { Parameters }\end{array}$ & $\begin{array}{l}\text { WHO } \\
\text { permissible } \\
\text { limits }\end{array}$ & Minimum & Maximum & Mean & $\begin{array}{l}\text { Standard } \\
\text { Deviation }\end{array}$ & $\begin{array}{l}\text { CV } \\
(\%)\end{array}$ & $\begin{array}{l}\text { No. of samples } \\
\text { exceeding the } \\
\text { permissible } \\
\text { imit of WHO }\end{array}$ & $\begin{array}{l}\% \text { of samples } \\
\text { exceeding the } \\
\text { Permissible } \\
\text { limit of WHO }\end{array}$ \\
\hline $\mathrm{pH}$ & $6.5-8.5$ & 6.0 & 7.9 & 6.5 & 0.4 & 6.2 & Nil & Nil \\
\hline $\mathrm{EC}(\mu \mathrm{S} / \mathrm{cm})$ & $500-1500$ & 410 & 2020 & 1162.8 & 404.17 & 34.8 & 4 & 16 \\
\hline TDS (mg/L) & $500-1000$ & 262 & 1293 & 744 & 259 & 34.8 & 4 & Nil \\
\hline TH (mg/L) & $100-500$ & 112.5 & 558 & 363.2 & 120.7 & 33.2 & 4 & 16 \\
\hline $\mathrm{HCO}_{3}^{-}(\mathrm{mg} / \mathrm{L})$ & $30-150$ & 73.20 & 549 & 264.74 & 98.49 & 37.2 & 22 & 88 \\
\hline $\mathrm{F}^{-}(\mathrm{mg} / \mathrm{L})$ & $0.6-1.5$ & 0.58 & 7.28 & 3.34 & 1.58 & 47.3 & 24 & 96 \\
\hline $\mathrm{Cl}^{-}(\mathrm{mg} / \mathrm{L})$ & $200-600$ & 55.26 & 1101.31 & 344.95 & 218.17 & 63.2 & 13 & 52 \\
\hline $\mathrm{NO}_{3}^{-}(\mathrm{mg} / \mathrm{L})$ & 50 & 0.08 & 1.48 & 0.54 & 0.56 & 104.1 & Nil & Nil \\
\hline $\mathrm{SO}_{4}{ }^{2-}(\mathrm{mg} / \mathrm{L})$ & 250 & 2.79 & 2374.87 & 548.22 & 642.83 & 117.3 & 11 & 44 \\
\hline $\mathrm{Na}^{+}(\mathrm{mg} / \mathrm{L})$ & $50-200$ & 30.01 & 215.01 & 105.35 & 50 & 47.5 & 1 & 4 \\
\hline $\mathrm{K}^{+}(\mathrm{mg} / \mathrm{L})$ & 200 & 0.98 & 18.79 & 3.46 & 3.35 & 96.8 & Nil & Nil \\
\hline $\mathrm{Ca}^{2+}(\mathrm{mg} / \mathrm{L})$ & $75-200$ & 12.22 & 88.67 & 47.23 & 15.69 & 33.2 & Nil & Nil \\
\hline $\mathrm{Mg}^{2+}(\mathrm{mg} / \mathrm{L})$ & $50-150$ & 6.16 & 45.11 & 23.70 & 11.34 & 47.9 & Nil & Nil \\
\hline
\end{tabular}




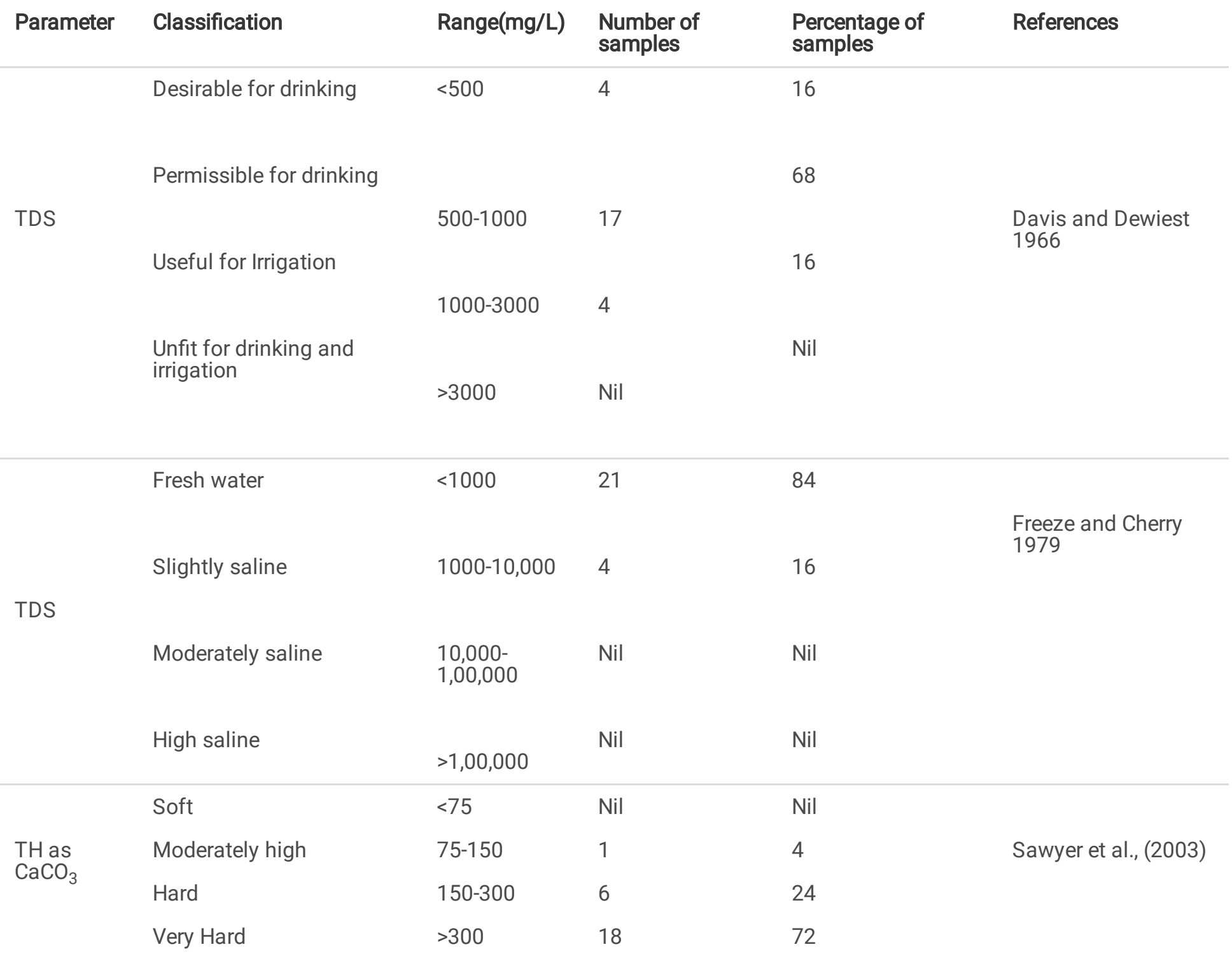

Table 4: Correlation coefficient of physicochemical parameters and major ions 


\begin{tabular}{|c|c|c|c|c|c|c|c|c|c|c|c|c|c|}
\hline & $\mathrm{pH}$ & EC & TDS & $\mathrm{HCO}_{3}^{-}$ & $\mathrm{F}^{-}$ & $\mathrm{Cl}^{-}$ & $\mathrm{NO}_{3}{ }^{-}$ & $\mathrm{SO}_{4}^{-}$ & $\mathrm{Na}^{+}$ & $\mathrm{K}^{+}$ & $\mathrm{Ca}^{2+}$ & $\mathrm{Mg}^{2+}$ & $\mathrm{TH}$ \\
\hline $\mathrm{pH}$ & 1.00 & & & & & & & & & & & & \\
\hline EC & -0.565 & 1.00 & & & & & & & & & & & \\
\hline TDS & -0.565 & 1.00 & 1.00 & & & & & & & & & & \\
\hline $\mathrm{HCO}_{3}^{-}$ & -0.701 & 0.564 & 0.564 & 1.00 & & & & & & & & & \\
\hline$F^{-}$ & -0.27 & 0.193 & 0.193 & 0.239 & 1.00 & & & & & & & & \\
\hline $\mathrm{Cl}^{-}$ & -0.324 & 0.869 & 0.869 & 0.23 & 0.198 & 1.00 & & & & & & & \\
\hline $\mathrm{NO}_{3}{ }^{-}$ & 0.401 & -0.083 & -0.083 & -0.137 & -0.03 & -0.086 & 1.00 & & & & & & \\
\hline $\mathrm{SO}_{4}^{-}$ & -0.273 & 0.592 & 0.592 & 0.167 & -0.12 & 0.365 & -0.023 & 1.00 & & & & & \\
\hline $\mathrm{Na}^{+}$ & -0.087 & 0.734 & 0.734 & 0.264 & 0.25 & 0.726 & 0.24 & 0.474 & 1.00 & & & & \\
\hline $\mathrm{K}^{+}$ & 0.042 & 0.344 & 0.344 & -0.008 & -0.24 & 0.289 & 0.086 & 0.618 & 0.451 & 1.00 & & & \\
\hline $\mathrm{Ca}^{2+}$ & 0.273 & -0.387 & -0.387 & -0.328 & -0.34 & -0.428 & 0.027 & -0.06 & -0.185 & 0.431 & 1.00 & & \\
\hline $\mathrm{Mg}^{2+}$ & -0.039 & 0.19 & 0.19 & 0.382 & 0.247 & 0.078 & -0.007 & -0.03 & 0.375 & -0.15 & -0.36 & 1.00 & \\
\hline TH & -0.67 & 0.884 & 0.884 & 0.648 & 0.218 & 0.708 & -0.196 & 0.516 & 0.409 & 0.099 & -0.55 & 0.16 & 1.00 \\
\hline
\end{tabular}

Table 5: WQI value of groundwater at individual sampling stations in Nacharam watershed

\section{Figures}




\begin{tabular}{|c|c|c|c|c|c|}
\hline Sample ID & Latitude & Longitude & Location & WQI & Water Quality Status \\
\hline GW01 & 17.43418 & 78.55267 & Baba Nagar & 40.231 & Excellent \\
\hline GW02 & 17.44317 & 78.57603 & Mallapur & 110.258 & Poor Water \\
\hline GW03 & 17.43901 & 78.57462 & Brahma Colony & 278.349 & Very Poor Water \\
\hline GW04 & 17.42937 & 78.57841 & Devendra Nagar & 61.225 & Good \\
\hline GW05 & 17.41571 & 78.58538 & Boduppal & 148.700 & Poor Water \\
\hline GW06 & 17.40795 & 78.58811 & Mallikarjuna Nagar & 243.198 & Very Poor Water \\
\hline GW07 & 17.39941 & 78.57285 & Sathya Nagar & 107.737 & Poor Water \\
\hline GW08 & 17.41855 & 78.56616 & Hema Nagar & 177.910 & Poor Water \\
\hline GW09 & 17.40903 & 78.5647 & Kaveri Nagar & 393.926 & Water unsuitable for drinking \\
\hline GW10 & 17.40728 & 78.55948 & Uppal Prasanthi Nagar & 214.874 & Very Poor Water \\
\hline GW11 & 17.41758 & 78.5415 & Habsiguda & 108.667 & Poor Water \\
\hline GW12 & 17.42559 & 78.54808 & HMT Bhavani Nagar & 142.999 & Poor Water \\
\hline GW13 & 17.43084 & 78.53166 & Vijayapuri & 116.151 & Poor Water \\
\hline GW14 & 17.43565 & 78.53957 & Shanti Nagar & 128.040 & Poor Water \\
\hline GW15 & 17.44358 & 78.53724 & Prem Vijay Nagar Colony & 297.509 & Very Poor Water \\
\hline GW16 & 17.45397 & 78.52922 & Goutham Nagar & 69.512 & Good \\
\hline GW17 & 17.4424 & 78.52041 & Thukaram Gate & 100.523 & Poor Water \\
\hline GW18 & 17.46467 & 78.53924 & Krupa Complex & 193.475 & Poor Water \\
\hline GW19 & 17.47462 & 78.53805 & New Vidhya Nagar & 235.424 & Very Poor Water \\
\hline GW20 & 17.47869 & 78.52488 & Neredmeti & 264.225 & Very Poor Water \\
\hline GW21 & 17.48761 & 78.52966 & Vivekandapuram & 189.008 & Poor Water \\
\hline GW22 & 17.48682 & 78.54431 & Sainikpuri & 182.147 & Poor Water \\
\hline GW23 & 17.47696 & 78.55808 & A.S Rao Nagar & 143.378 & Poor Water \\
\hline GW24 & 17.46308 & 78.55901 & Eshwar Nagar Colony & 262.331 & Very Poor Water \\
\hline GW25 & 17.45387 & 78.55421 & Musi Nagar & 186.521 & Poor Water \\
\hline
\end{tabular}




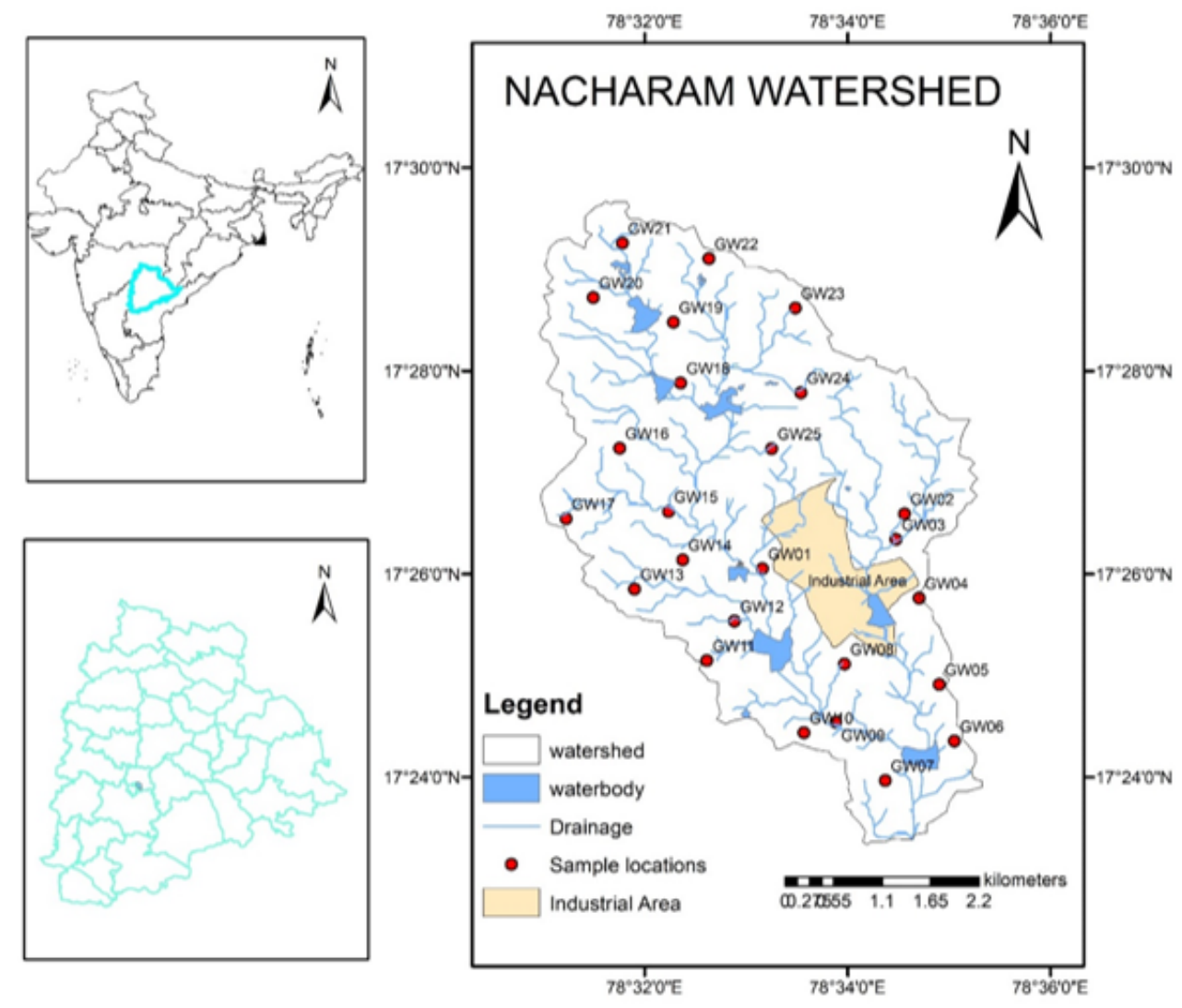

Figure 1

Location map and sampling stations of Nacharam watershed with demarcation of industrial area. 

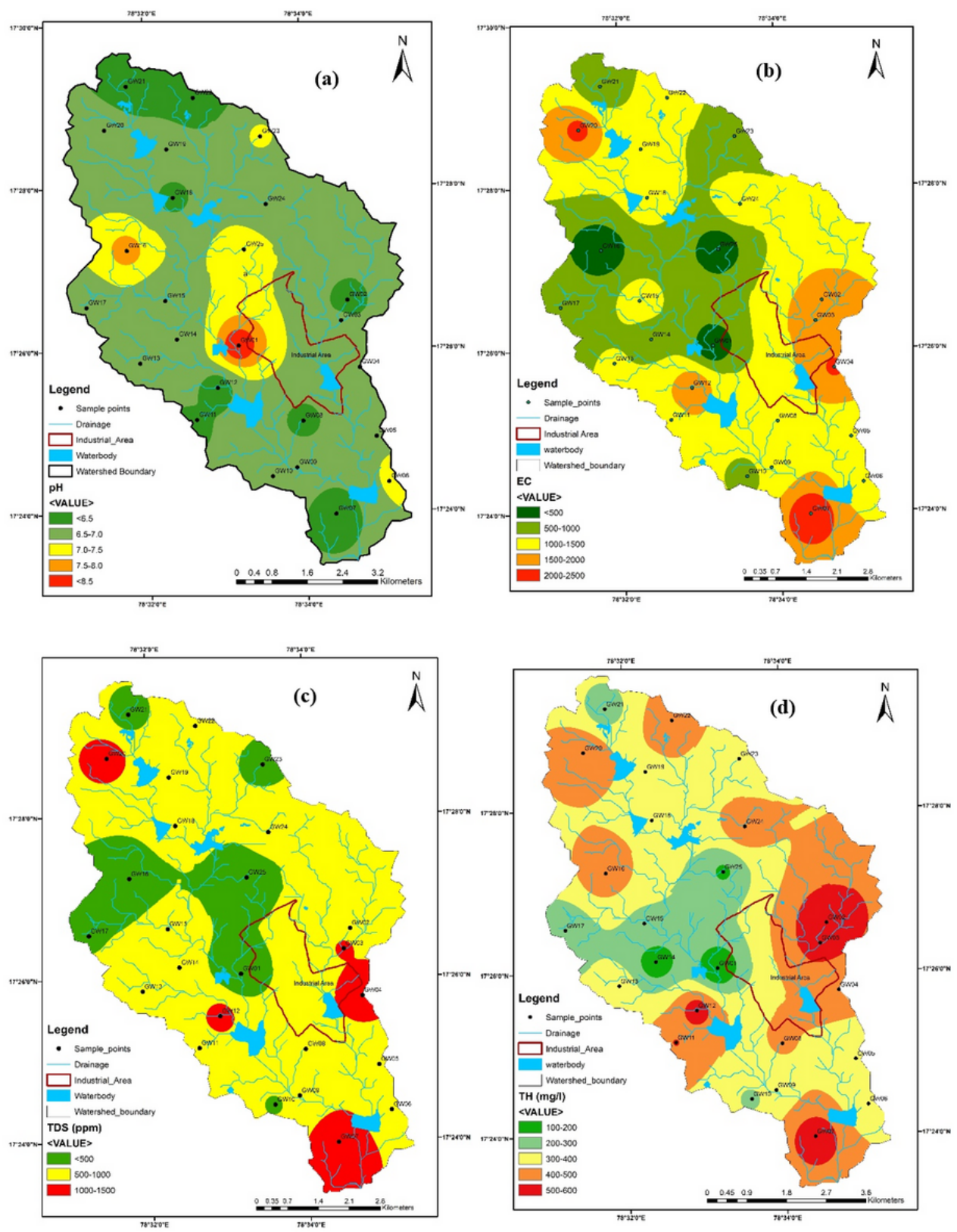

Figure 2

Spatial distribution maps of (a) pH, (b) EC, (c) TDS, and (d) TH in groundwater 

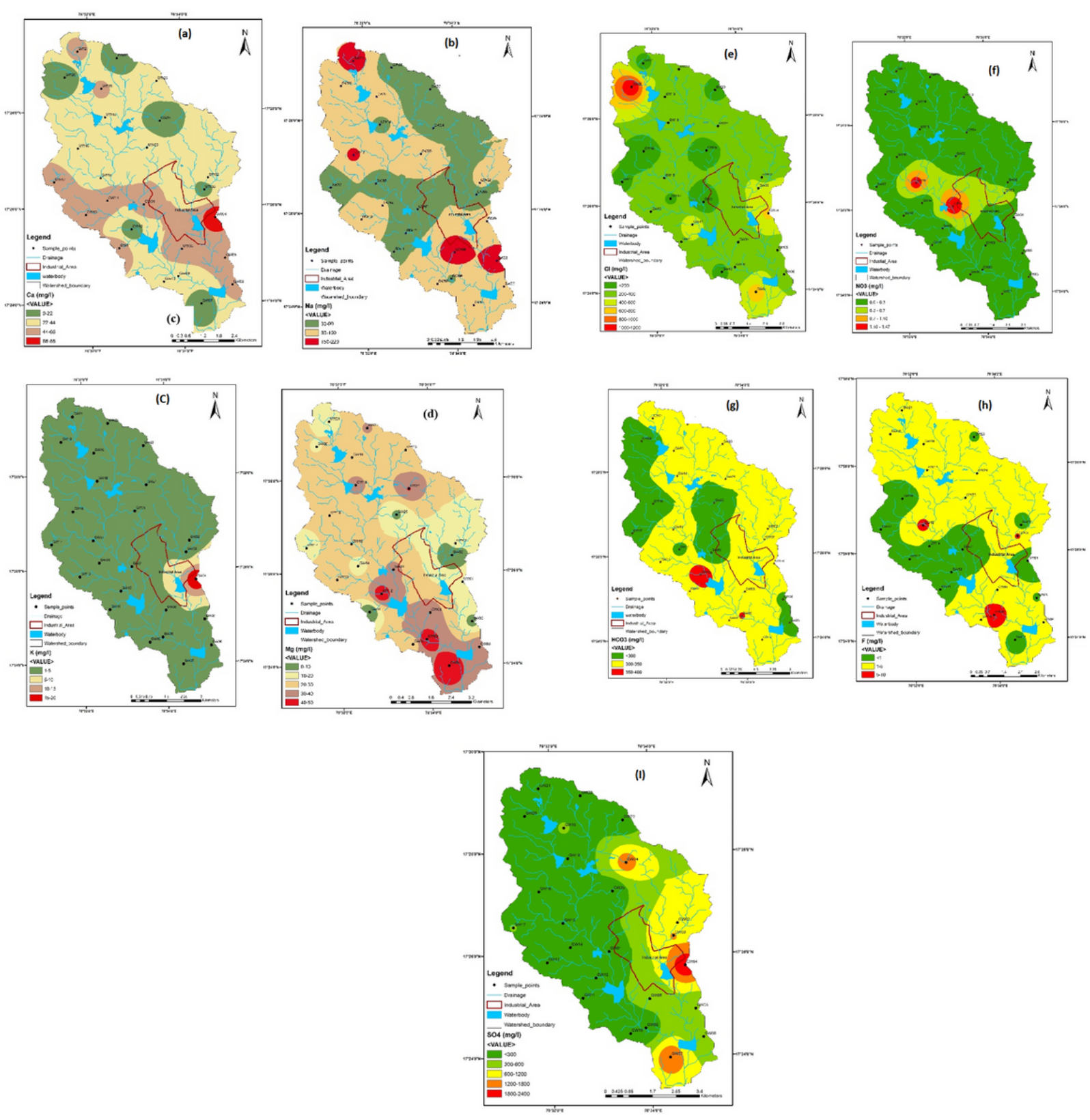

Figure 3

Spatial distribution maps of major cations (a)-(d) and anions (e) - (i) in groundwater 
A-Calcium type

B-No Dominant

C-Magnesium type

D-Sodium type

E-Bicarbonate type

F-Sulphate type

G-Chloride type

(I) $\mathrm{Ca}-\mathrm{Mg}-\mathrm{Cl}-\mathrm{SO}_{4}$

(II) $\mathrm{Na}-\mathrm{K}-\mathrm{Cl}-\mathrm{SO}_{4}$

(III) $\mathrm{Na}-\mathrm{K}-\mathrm{HCO}_{3}$

(IV) $\mathrm{Ca}-\mathrm{Mg}-\mathrm{HCO}_{3}$

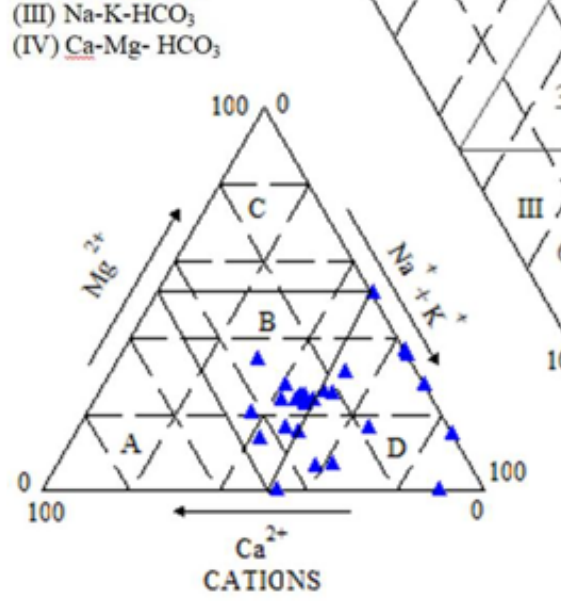

100

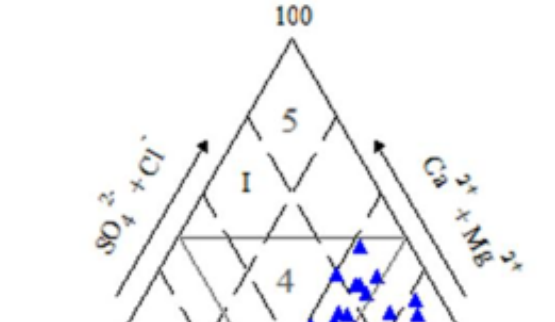

1. $\mathrm{Ca}^{2+}-\mathrm{HCO}_{3}{ }^{-}$

2. $\mathrm{Na}^{+}-\mathrm{Cl}^{-}$

3. Mixed $\mathrm{Ca}^{2+}-\mathrm{Na}^{+}-\mathrm{HCO}_{3}^{-}$

4. Mixed $\mathrm{Ca}^{2+}-\mathrm{Mg}^{2+}-\mathrm{Cl}^{-}$

5. $\mathrm{Ca}^{2+}-\mathrm{Cl}^{-}$

6. $\mathrm{Na}^{2+}-\mathrm{HCO}_{3}^{-}$

Figure 4

Piper trilinear diagram for groundwater samples from the study area 
(a)

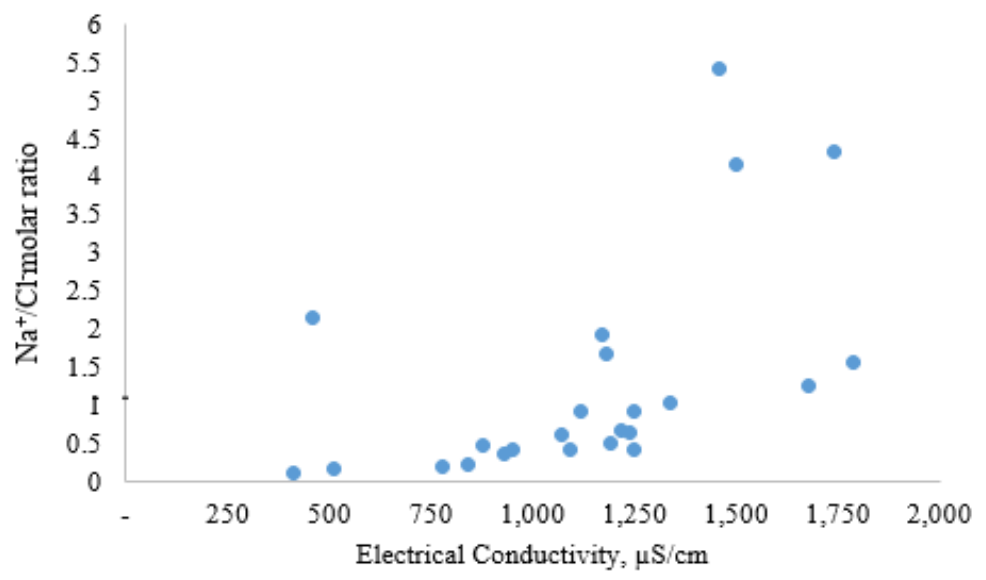

(b)

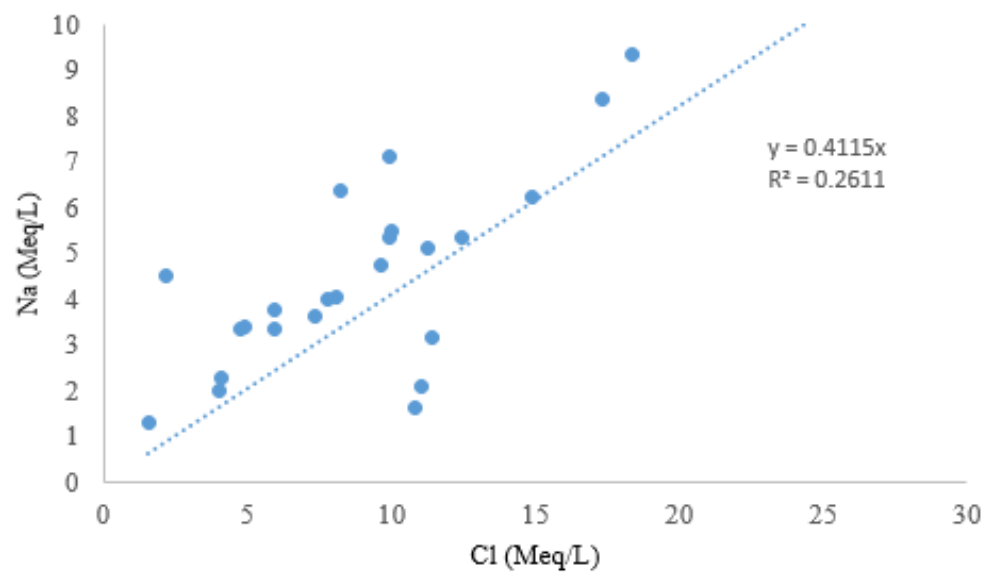

Figure 5

$\mathrm{Na}+/ \mathrm{Cl}$ - ratio plot of groundwater samples from Nacharam watershed 
(a)

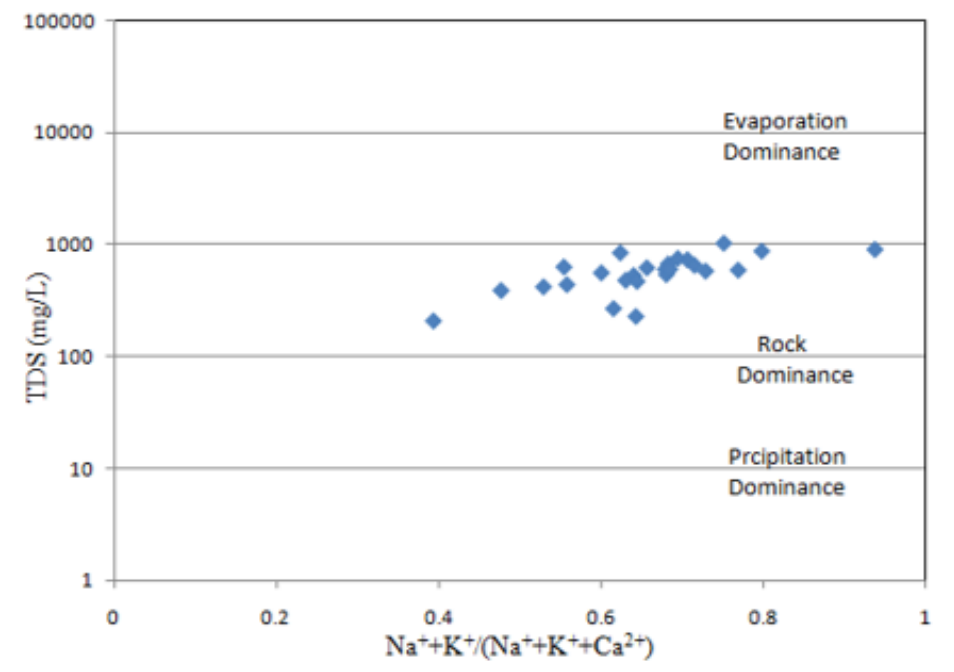

(b)

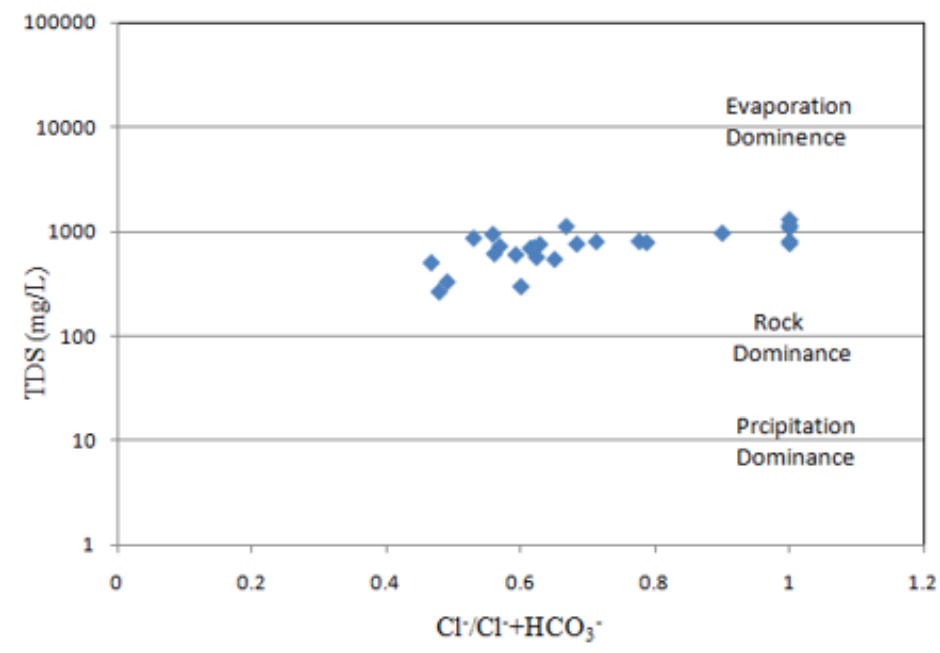

Figure 6

Mechanism controlling groundwater chemistry for study area (a) TDS vs. (Cl-)/(Cl- + $\mathrm{HCO}-)$; (b) TDS vs. $(\mathrm{Na}++\mathrm{K}+) /(\mathrm{Na}++\mathrm{K}++\mathrm{Ca} 2+)$ 


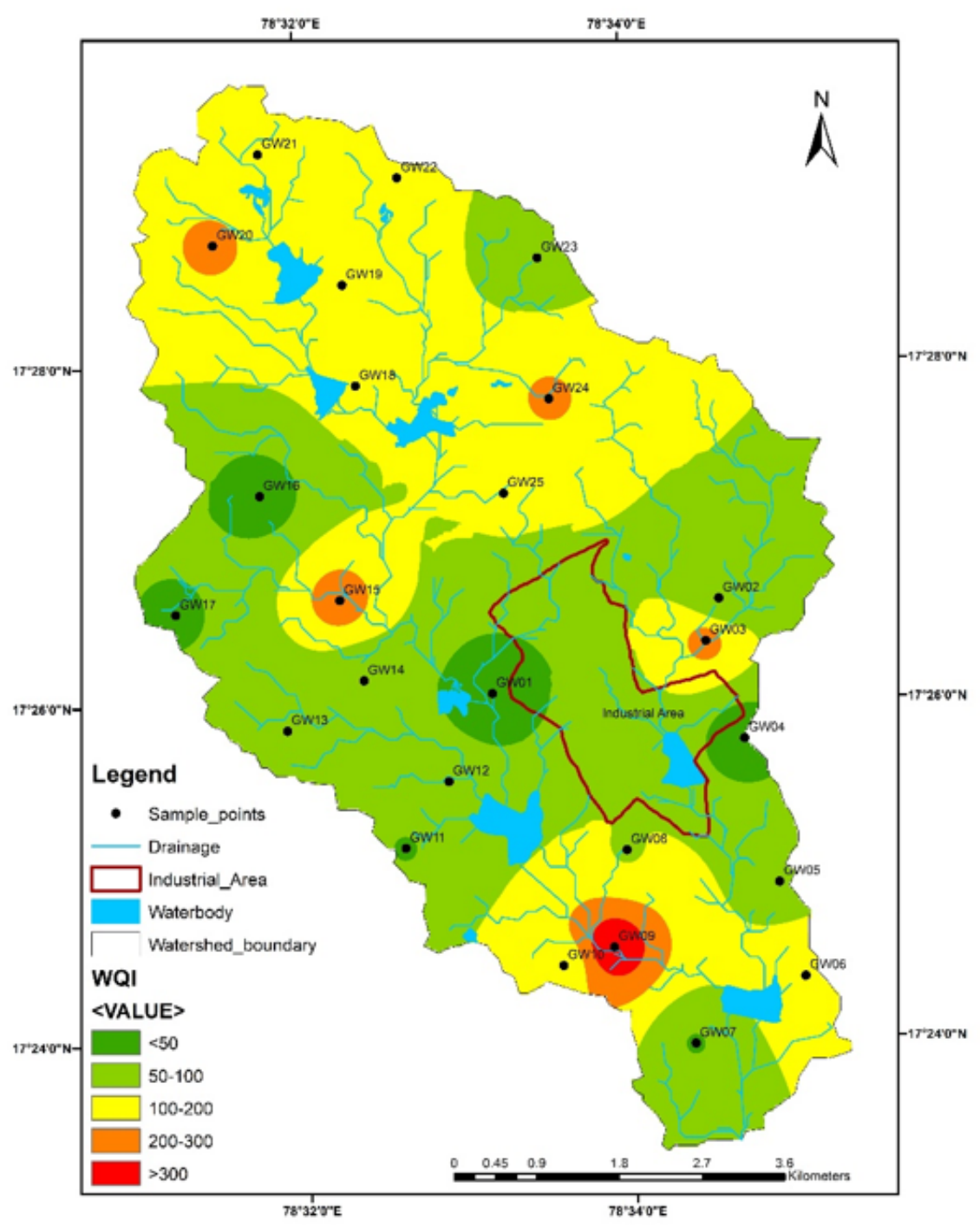

\section{Figure 7}

Distribution map of Water Quality Index (WQI) values in Nacharam watershed

\section{Supplementary Files}

This is a list of supplementary files associated with this preprint. Click to download.

- krmsupplementarydata.docx 